\title{
Correction: Treatment and cost of pressure injury stage III or IV in four patients with spinal cord injury: the Basel Decubitus Concept
}

\author{
Christine Meier ${ }^{1,2}$ - Stefan Boes ${ }^{2} \cdot$ Armin Gemperli $^{2,3} \cdot$ Hans Peter Gmünder $^{1} \cdot$ Kamran Koligi $^{1}$ - Stefan Metzger ${ }^{1}$. \\ Dirk J. Schaefer ${ }^{4} \cdot$ Klaus Schmitt $^{1} \cdot$ Wolfram Schwegmann $^{1} \cdot$ Reto Wettstein ${ }^{4} \cdot{\text { Anke Scheel-Sailer } \mathbb{B}^{1,2}}^{1,2}$
}

(c) The Author(s) 2019. This article is published with open access

\section{Correction to: Spinal Cord Series and Cases 5:30 \\ https://doi.org/10.1038/s41394-019-0173-0 \\ published online 15 March 2019}

This article was originally published under standard licence, but has now been made available under a [CC BY 4.0] license. The PDF and HTML versions of the paper have been modified accordingly.
Open Access This article is licensed under a Creative Commons Attribution 4.0 International License, which permits use, sharing, adaptation, distribution and reproduction in any medium or format, as long as you give appropriate credit to the original author(s) and the source, provide a link to the Creative Commons license, and indicate if changes were made. The images or other third party material in this article are included in the article's Creative Commons license, unless indicated otherwise in a credit line to the material. If material is not included in the article's Creative Commons license and your intended use is not permitted by statutory regulation or exceeds the permitted use, you will need to obtain permission directly from the copyright holder. To view a copy of this license, visit http://creativecommons. org/licenses/by/4.0/.
Anke Scheel-Sailer

anke.scheel-sailer@paraplegie.ch

Swiss Paraplegic Centre (SPC), Nottwil, Switzerland

2 Department of Health Sciences and Health Policy, University of Lucerne, Lucerne, Switzerland

3 Swiss Paraplegic Research (SPF), Nottwil, Switzerland

4 Swiss Department of Plastic, Reconstructive, Aesthetic and Hand Surgery, University Hospital, Basel, Switzerland 